\title{
BARONG LANDUNG: AKULTURASI BUDAYA BALI DAN TIONGHOA
}

\author{
BARONG LANDUNG: THE ACCUTURATUON OF BALINESE AND \\ CHINESE CULTURE
}

Ni Made Ayu Erna Tanu Ria Sari

INSTITUT HINDU DHARMA NEGERI DENPASAR

Jl. Ratna No. 51 Tatasan Denpasar Bali, Telp. (0361) 226656

E-mail : thalitaayu1@gmail.com

DOI: 10.36424/jpsb.v6i2.199

Naskah Diterima: 29 Agustus 2020 Naskah Direvisi: 18 Nopember 2020

Naskah Disetujui: 20 Nopember 2020

\begin{abstract}
Abstrak
Aktivitas keagamaan masyarakat Bali senantiasa berhubungan dengan seni tari Bali memiliki banyak jenis tari-tarian. Tari barong banyak dijumpai di Bali dengan beberapa jenisnya, salah satunya Barong Landung yang merupakan perwujudan manusia atau raksasa. Inilah kemudian oleh masyarakat Bali dimaknai sebagai suatu kekuatan yang diyakini memberikan keselamatan. Permasalahan penelitian difokuskan pada sejarah munculnya Barong Landung, Barong Landung sebagai simbol keterkaitan Pura Dalem Balingkang dengan Barong Landung. Penelitian menggunakan metode kualitatif dengan analisis pada data wawancara, observasi, dan data sekunder. Dari hasil penelitian ditemukan bahwa Barong Landung adalah perwujudan dari sang Maha Pencipta itu sendiri, yang oleh undagi di masa lalu tentu diwujudkan sesuai dengan keadaan zamannya ketika itu, yakni ketika sedang hangat-hangatnya perkawinan antarbudaya Cina dan Bali. Pesona tarian ini umumnya hanya bisa dinikmati pada momen-momen khusus seperti hari besar keagamaan di Bali biasa disebut Piodalan yang dilangsungkan di purapura tertentu.
\end{abstract}

Kata Kunci : Akulturasi Budaya, Bali, Barong Landung,

\section{Abstract}

The majority of Balinese are Hindus. The religious activities for Hindus in Bali are always associated with dance. Bali has many types of dances. One of them is Barong. In Bali, there are several types of Barong. One of them is Barong Landung. Barong Landung represents a human or a giant. This is then interpreted by the Balinese people as a power that is believed to give 
them safety. It is strongly believed by the people in Bali, especially Hindus, that the existence of Barong Landung is always exalted and sanctified. This phenomenon is very interesting to be revealed. Therefore, the research problems in this study were focused on the history of the emergence of Barong Landung, the symbolism behind Barong Landung, and the relationship between Pura Dalem Balingkang and Barong Landung. In order to collect and analyze the data in this study, this research used qualitative methods with analysis of interview data, observation, and secondary data. From the research results, it was found that Barong Landung is the embodiment of the Creator himself. In the past, the undagi was inspired based on the social situation in that era. At that time, there were some cases related to the intercultural marriage of China and Bali. Nowadays, the charm of this dance in general can only be enjoyed on special moments such as religious holidays in Bali, usually called Piodalan, which is held in certain temples.

Keywords: Cultural Acculturation, Bali, Symbolism

\section{PENDAHULUAN}

Kebudayaan Bali dikenal karena tradisi dan kesenian yang dimiliki dikenal oleh masyarakat dunia. Berkat kebudayaannya melalui pariwisata, masyarakat Bali tetap mempertahankan tradisi seiring dengan perkembangan zaman, sehingga kebudayaan Bali terus bertahan di mata dunia. Kebudayaan Bali juga merupakan suatu kebudayaan yang hidup secara fungsional dan selalu berkembang untuk memelihara keserasian hubungan manusia dengan Tuhan, manusia dengan lingkungan dan manusia dengan manusia. Ketiga hubungan tersebut di Bali dikenal dengan istiah Tri Hita Karana (Wiana, 2003:16).

Kehadiran barong dalam setiap kegiatan masyarakat, khususnya pada pelaksanaan upacara keagamaan memegang peranan penting dan selalu menjadi pusat perhatian. Pertunjukan barong di Bali merupakan bentuk kesenian yang tergolong dalam seni wali, bebali, dan balih-balihan. Barong menjadi kebanggaan karena menjadi simbol kekuatan magis, kemegahan, dan keagungan yang dipancarkannya. Masyarakat Bali memaknai kekuatan magis yang ada pada barong menjadi pelindung dan penjaga keselamatan mereka (Wijaya, 2001:38).. 
Aktivitas keagamaan penduduk Bali yang mayoritas beragama Hindu dalam aktivitas keagamaannya selalu berhubungan dengan kesenian (seni tari), bahkan merupakan peranan yang sangat penting. Bali memiliki banyak jenis tari-tarian. Tari barong banyak dijumpai di Bali dengan beberapa jenisnya, diantaranya ada yang berwujud binatang berkaki empat, seperti Barong Macan, Barong Lembu, Barong Asu, Barong Ket, Barong Bangkal, dan Barong Gajah, serta Barong Blas-blasan. Barong Landung dan Barong Brutuk itu keduanya merupakan perwujudan manusia atau raksasa.

Ketika mendengar nama Barong Landung, yang akan terpikirkan adalah sosok mahluk yang tinggi besar, menyeramkan dan angker. Inilah kemudian oleh masyarakat umum memaknainya sebagai suatu kekuatan yang diyakini memberikan kerahayuan dan keselamatan. Dua makna inilah yang menarik untuk disimak lebih lanjut. Makna ini biasanya dikaitkan dengan cerita rakyat yang sudah melegenda di Bali, antara lain : Dalem Balingkang, Jayapangus, Kang Cing Wie dan lain sebagainya. Sangat diyakini oleh masyarakat di Bali sehingga keberadaannya selalu diagungkan dan disucikan. Begitu jelas, bahwa makna universal Barong Landung yakni sebagai simbolisme kekuatan Tuhan yang hadir sebagai manifestasi yang mempunyai aspek magis-religius.

Segara (2000 : 9) dijelaskan bahwa secara etimologi kata Barong berasal dari bahasa Sanskerta yaitu kata $B(h)$ arwang yang dalam bahasa Melayu atau bahasa Indonesia sejajar dengan kata beruang yaitu nama seekor binatang yang hidup di daerah Asia, Amerika dan Eropa, berbulu tebal dan hitam serta ekornya pendek.

Pendapat lain juga ada yang menyebutkan bahwa Barong berasal dari urat kata ba-ru-ang. Dalam bahasa Indonesia ada sistem sandi (peluluhan vokal) sehingga $\mathrm{u}$ - a disandikan menjadi o, sehingga kata ba-ru-ang menjadi kata barong. Rong mengandung makna ruang, rongga. Jadi dengan demikian Barong itu adalah sesuatu yang berisi ruang atau rongga. Sedangkan Landung (bahasa Bali) mengandung arti tinggi. Jadi Barong Landung adalah sesuatu benda yang menyerupai manusia dan dibuat dengan menggunakan ruang atau 
rongga sebagai tempat untuk mundut. Barong Landung merupakan Barong yang bentuknya lain dengan Barong yang umum di Bali (Barong Ket) yang berbentuk tinggi besar. Wujud Barong Landung ini umumnya ada dua yaitu berwujud laki-laki tinggi besar dan berwarna hitam yang disebut Jero Gede, dan yang perempuan tinggi berkulit putih dan bermata sipit disebut Jero Luh. Demikian juga halnya Barong Landung yang ada di Pura Batur Panti Desa Pakraman Tambawu terdiri dari empat buah yaitu Jero Gede, Jero Luh, Mantri dan Galuh.

Barong Landung, dilihat dari namanya, memiliki bentuk yang tinggi. Landung berarti tinggi. Wujudnya berupa manusia dengan tinggi bisa mencapai 3 meter. Barong Landung banyak dijumpai disekitar Bali Selatan, seperti Badung, Denpasar, Gianyar, Tabanan.

Sejarah Barong Landung dimulai pada abad VI. Ketika itu Raja Sri Jaya Kesunu memiliki seorang istri dan anak bernama Mayadenawa. Raja Jaya Kesunu murung dan akibatnya, kerajaan tidak terurus. Maka Mayadenawa dinobatkan sebagai Raja Bali menggantikan ayahnya Jaya Kesunu, untuk menghilangkan kesedihan Jaya Kesunu, penasihat kerajaan berinisiatif menjodohkan dengan salah seorang putri dari saudagar Cina bernama Kang Cing We sebagai istri kedua dari Jaya Kesunu. Kecantikan Kang Cing We membuat Jaya Kesunu pun menerima perjodohan itu. Sejak itu Raja Jaya Kesunu pun kembali terlihat gembira. Tapi sayang, keinginan dari Raja Jaya Kesunu untuk mendapat keturunan dari Kang Cing We tidak terkabul, karena sang permaisuri mandul.

Meskipun demikian, cinta Jaya Kesunu dengan Kang Cing We tidak pernah surut. Saking cintanya pada putri Kang Cing We, Raja Jaya Kesunu hendak memerintahkan Empu Liem membuat satu tarian yang melambangkan dirinya dengan putri Kang. Mpu Lien kemudian membuat dua patung besar menyerupai manusia yang bisa ditarikan. Patung yang satu berwajah laki-laki dengan karakter wajah lokal berwarna hitam sebagai lambang Jaya Kesunu. Satu lagi adalah perempuan berwajah putih dengan muka cemberut tetapi memancarkan sinar keibuan sebagai lambang putri Kang. Keduanya 
kemudian disebut Barong Landung. Dari cerita ini ada petunjuk, bahwa pernah terjadi perkawinan antara Raja Bali dengan putri Cina

Berdasarkan latar belakang di atas maka permasalahan yang dapat dirumuskan sebagai berikut : Sejarah munculnya Barong Landung, Barong Landung sebagai simbol pura Dalem Balingkang dan keterkaitannya dengan Barong Landung. Tujuan Penelitian Untuk mengetahui Sejarah munculnya Barong Landung, Untuk mengetahui Barong Landung sebagai simbolisme, Untuk mengetahui Pura Dalem Balingkang dan keterkaitannya dengan Barong Landung.

Berdasarkan sejarah estetika terdapat tiga teori tentang dorongandorongan manusia menciptakan seni. Ketiga teori itu adalah : Theory of play : yaitu lahirnya seni itu semat-mata untuk kesenangan saja dan untuk mengisi waktu yang luang. Theory of utility: yaitu semua kesenian artistic yang dilakukan manusia yang ditujukan untuk kepentingan praktis dan kebutuhan social. Theory magi dan Religi : yaitu kelahiran seni itu guna memperoleh tenaga gaib keperluan berburu dan kepentingan lain Kadir (1975: 3-4).

\section{METODE PENELITIAN}

Jenis penelitian yang digunakan dalam penelitian ini adalah penelitian kualitatif. Data yang terkumpul berupa hasil wawancara dan observasi direduksi, dipilah-pilah atau diklasifikasi sesuai dengan fokus penelitian. Data hasil wawancara dan observasi selanjutnya disentesakan dengan teori. Selanjutnya dilakukan penulisan laporan hasil akhir penelitian yang merupakan hasil penafsiran dan interpretasi terhadap data lapangan setelah disentesakan dengan konsep dan teori yang relevan.

Pemilihan informan diawali dengan penentuan informan kunci (key informan) yang dikembangkan dengan teknik snowball. Selanjutnya informan kunci ini diminta pertimbangan secara berangkai untuk menentukan informan lainnya. Demikian seterusnya sehingga jumlah informan bertambah sampai informasi yang diperolehpun iharapkan semakin kaya. Jumlah informan tidak dibatasi, tergantung pada tingkat kejenuhan data. Artinya, bila informasi atau 
data yang diperoleh sudah menunjukan kesamaan maka dianggap telah memadai. Infoman yang dipakai dalam penelitian ini adalah Dr. Drs. I Ketut Tanu sebagai dosen Sejarah Kebudayaan dan Dr. Dewa Ketut Wisnawa,S.Ag.,M.Ag dosen Seni Sakral yang kedua informan merupakan dosen di Institut Hindu Dharma Negeri Denpasar.

Instrumen peneltian yang digunakan adalah pedoman wawancara, Pedoman observasi, kamera, alat perekam, dan catatan lapangan (field note). Pedoman wawancara merupakan sejumlah pertanyaan terbuka yang digunakan sebagai acuan untuk memperoleh informasi dari subjek. Pedoman observasi ialah kisi-kisi sebagai panduan yang digunakan dalam penelitian ini untuk mengetahui sejarah Barong Landung.

Alat perekam dan kamera digunakan untuk merekam secara utuh data yang diperoleh dari subjek. Catatan lapangan digunakan untuk mencatat berbagai fenomena dan informasi yang tidak dapat direkam dengan alat perekam. Selain Intrumen penelitian tersebut, peneliti sendiri merupakan alat utama dalam penelitian ini.

Wawancara juga difokuskan untuk memahami pementasan Tari Barong Landung di Bali. Studi Kepustakaan dan Dokumen merupakan kegiatan yang cukup penting dalam penelitian ini studi kepustakaan yang berasal dari buku-buku serta sumber tertulis baik tercetak mauppun elektronik lainnya. Data kepustakaan yang sesuai untuk penelitian ini diharapkan mampu melengkapi data primer yang berhasil dikumpulkan dalam penelitian tentang pementasan Tari Barong Landung

\section{PEMBAHASAN}

Sejarah munculnya Barong Landung

Abad ke-16 yakni pada pemerintahan Dalem Waturenggong, seni dan budaya Bali dinilai sejumlah pakar telah mencapai puncaknya. Saat itu telah diciptakan relief Boma, yang kemudian menjadi tapel Barong Ket. Disamping itu pula terdapat tulisan Banaspati dan Calonarang, keduanya menunjuk pada pengertian Barong. 
biasanya untuk mengagumkan sesuatu dalam proses berkarya para undagi, kreator, atau senimannya-sering mewujudkan pujaannya itu jauh lebih besar dari dirinya. Ini semata-mata untuk menunjukkan betapa besar kekuatan Tuhan, dan betapa kecil dirinya. Dalam kasus Barong Landung ini misalnya, undagi sengaja membuat wujud yang sangat menyeramkan dengan harapan dapat mengimbangi kedasyatan roh-roh jahat yang sering mengganggu kehidupan manusia di desa-desa. jika disimpulkan, Barong Landung adalah perwujudan dari sang Maha Pencipta itu sendiri, yang oleh para undagi di masa lalu tentu diwujudkan sesuai dengan keadaan zamannya ketika itu, yakni ketika hangat-hangatnya perkawinan antarbudaya Cina dan Bali.

Barong Landung adalah mahakarya para leluhur di Bali. Barong landung adalah lambang penciptaan yang oleh ilmuan Thomas Alfa Edison disebut sebagai unsur positif dan negatif. Diyakini, jika kedua unsur ini bertemu, maka akan menimbulkan energi listrik. Ada juga sumber mengatakan, bahwa barong ini mula-mula dipakai untuk mengetahui barisan makhluk halus ganas yang menebar segala bencana penyakit dan marabahaya ke Ratu Gede Mecaling.

Barong adalah topeng yang berwujud binatang mitologi yang memiliki kekuatan gaib dan dijadikan pelindung masyarakat Bali Bandem (2011: 86). Dilihat fungsinya, barong-barong di Bali juga melakukan perjalanan ke luar desanya, berkeliling mengunjungi desa lain, mengadakan pementasan di jalan raya atau rumah orang secara profesional, memungut uang untuk kepentingan kesejahteraan seka atau banjar pemilik barong itu atau disebut dengan nglawang Bandem (2011: 88). Dalam artikelnya, Bandem (2011) juga menceritakan mitos Jayapangus yang menikah dengan putri asal Cina bernama Kang Cing Wei hingga perjalanan kehidupan rumah tangga yang belum dikaruniai anak. Raja memutuskan bertapa di dekat Gunung Batur. Dalam pertapaannya raja menikah dengan Dewi Danu yang merupakan putri dari Batari Batur. Pernikahan tersebut akhirnya diketahui Kang Cing Wei. Putri murka. Terjadi pertengkaran dengan Dewi Danu. 
Akhirnya, Batari Batur melebur Jayapangus dan Kang Cing Wei. Masyarakat Batur memohon kepada Batari Batur agar diizinkan membuat patung suci (pratima) Jayapangus dan Kang Cing Wei.

Barong Landung adalah simbol Dewa yang dipergunakan sebagai alat untuk memuja Tuhan atau di Bali deikenal dengan istilah (Pralingga) yang sekaligus perisai bagi desa-desa yang terancam wabah penyakit. Bahkan di banyak tempat, Barong Landung dipuja sebagai simbol sejarah yang sangat kelam di masa lalu. Barong Landung memiliki kisah sejarah di masa silam yaitu ketika Raja Bali dari dinasti Warmadewa (kerajaannya berpusat di Panarojan, tiga kilometer di sebelah utara Kintamani) yang bernama Sri Jaya Pangus, dalam versi cerita ini disebutkan bahwa Sri Jaya Pangus dituduh telah melanggar adat yang sangat ditabukan saat itu, yakni telah dengan berani mengawini putri Cina yang elok bernama Kang Cing Wei. Meski tidak mendapatkan berkat dari pendeta kerajaan, Mpu Siwa Gama, sang raja tetap ngotot tidak mau mundur. Akibatnya, sang pendeta marah, lalu menciptakan hujan terus menerus, hingga seluruh kerajaan tenggelam.

Dengan berat hati sang raja memindahkan kerajaannya ke tempat lain, kini dikenal dengan nama Balingkang. Kata "balingkang" terdiri dari kata "bali" dan "kang". Bali berarti Pulau Bali dan "Kang" sama dengan "king" yang berarti "raja". Raja kemudian dijuluki oleh rakyatnya sebagai Dalem Balingkang. Sayang, karena lama Kang Cing Wei tidak mempunyai keturunan, raja pun pergi ke Gunung Batur, memohon kepada dewa di sana agar dianugrahi anak. Dalam perjalanannya sang raja bertemu dengan Dewi Danu yang wajahnya cantik jelita. Sang raja pun terpikat, dan akhirnya menikah. Dari perkawinan ini, lahirlah seorang anak lelaki yang diberi nama Maya Denawa. Anak lelaki ini kemudian namanya sangat terkenal, terutama jika dihubungkan dengan perayaan Hari Raya Galungan di Bali.

Sementara itu, Kang Cing Wei yang lama menunggu suaminya pulang, mulai gelisah. Akhirnya, Kang Cing Wei pun bertekad menyusul ke Gunung Batur. Namun ketika berada di tengah hutan belantara, Kang Cing Wei terkejut saat menemukan suaminya telah menjadi milik dari Dewi Danu. 
Ketiganya lalu terlibat pertengkaran sengit. Dewi Danu dengan marah berapiapi menuduh sang raja telah membohongi dirinya dengan mengaku sebelumnya sebagai perjaka. Dengan kekuatan gaibnya, Dewi Danu melenyapkan Dalem Balingkang dan Kang Cing Wei dari bumi ini. Oleh rakyat yang mencintainya, Dalem Balingkang dan Kang Cing Wei dibuatkan patung yang dikenal dengan nama Stasura dan Bhati Mandul. Patung inilah kemudian berkembang menjadi Barong Landung. Keberadaan Barong Landung ternyata lebih dari sekadar sejarah bahkan bukan saja merupakan perkawinan lahiriah, tetapi juga bisa disebut perkawinan budaya, pernikpernik budaya Cina seperti pis bolong, patra cina, barong sae, telah lama "dikawinkan" dengan budaya Bali, bahkan dalam bidang filsafat telah pula melahirkan paham siwa Budha yang terus memperkaya tradisi agama Hindu sampai sekarang di Bali.

\section{a. Barong Landung Sebagai Simbolisme}

Sebelum mengulas tentang Barong Landung sebagai simbolisme, terlebih dahulu akan diuraikan pengertian dari pada Barong Landung tersebut. Memang memberikan pengertian secara umum mengenai Barong dan secara khusus mengenai Barong Landung sangatlah sulit, mengingat beberapa sumber yang ada memberikan pengertian yang berbeda. Masyarakat Hindu di Bali dalam mengadakan komunikasi dengan Tuhan tidak hanya melalui hubungan spiritual secara langsung namun juga mempergunakan media simbol. Menurut Ernst Cassier manusia dikatakan sebagai animal symbollicum. Penciptaan simbol merupakan respon ekspresif manusia terhadap situasi alam yang melingkupinya (Triguna, $2000: 2$ ).

Perwujudan tokoh yang laki-laki dengan muka seram berwarna hitam disebut Jero Gede, sedangkan tokoh wanita dengan muka lucu (mata sipit, jidat dan pipi menonjol, kuping lebar) berwarna putih atau kuning disebut Jero Luh. Kedua tokoh ini adalah tokoh sentral yang harus ada sebagai lambang pemujaan, dan untuk tujuan pemenuhan lakon pertunjukkan dapat ditambah dua sampai tiga tokoh lainnya (Warna, 1993: 63). 
Masing-masing pengertian ini tetap bertahan dan sama-sama mengandung kebenaran. Makna simbolisisme dalam Barong landung lainnya disarikan dan dimodifikasi dari hasil penelitian Gadung (2008: 152-155), sebagai berikut :

1. Rambut Jero Gede (Barong Landung Laki-Laki) yang terurai hitam panjang dijadikan sebagai simbol, bahwa dalam menjalankan rangkaian kehidupan, manusia tidak dapat terlepas dari kepanasan hingga kekeringan. Sementara itu rambut Jero Luh (Barong Landung Perempuan) yang disimbolkan dengan posisi disanggul, dilambangkan sebagai suasana hati yang sejuk, serta mampu menyejukkan udara yang panas dalam kehidupan. Simbol rambut Jero Gede dan Jero Luh menggambarkan keberadaan Barong Landung sebagai penjaga semesta beserta isinya. Melalui pemujaan simbol ini, umat pun berharap terwujudnya keseimbangan alam dan terhindar dari marabahaya.

2. Mata Jero Gede (Barong Landung Laki-Laki) yang melotot, simbol maha melihat atau mengetahui, dapat memantau baik-buruk, benar-salah prilaku ciptaan-Nya di Bumi. Jero Luh (Barong Landung Perempuan) bermata sipit dengan jidat menonjol (jantuk), simbol ketenangan dalam memikirkan apa yang harus dilakukan kala ada masalah yang menimpa ciptaan-Nya di Bumi. Inti nilai yang dikandungnya, manusia harus bisa membedakan antara yang baik dan buruk, antara yang benar dan yang salah, sehingga mampu menghadapi masalah dengan tenang dan menempatkan kebenaran, kebajikan di atas segala kebatilan, kesalahan.

3. Mulut Jero Gede (Barong Landung Laki-Laki) yang lebar dengan gigi tongos dan bertaring adalah simbol kemurkaan dan kegeraman dan kemahakuasaan. Sedangkan Jero Luh (Barong Landung Perempuan) tersenyum simpul, simbol kelembutan dan kehalusan budi atau hati. Makna semuanya adalah segala masalah dalam kehidupan ini tidak boleh diselesaikan dengan kekerasan, melainkan harus dengan kepala dingin dan kelembutan budi atau hati untuk tercapainya mufakat. Setiap kekerasan harus dilawan dengan kelembutan dan ketabahan (bukan 
dengan kekerasan) demi tercapainya ketenangan dalam kehidupan bermasyarakat.

4. Warna kulit Jero Gede (Barong Landung Laki-Laki) hitam dan Jero Luh (Barong Landung Perempuan) putih adalah simbol rwa bhineda yaitu dua unsur yang selalu bertentangan tetapi harus tetap berpasangan (binnary oppotition), yang akan melahirkan keserasian, keselarasan dan keseimbangan. Makna simbolisnya, masyarakat harus mampu menerima adanya sifat dualistis tersebut secara bijaksana, menerima perbedaan sebagai sebuah dinamika yang memang dibutuhkan dalam memacu gerak maju kehidupan ini.

5. Badan barong landung tinggi besar dengan salah satu tangan bertolak pinggang, adalah simbol kegagah-beranian dalam menghadapi segala tantangan dan berbagai ancaman yang ingin mengancam keselamatan dan kedamaian masyarakat. Makna intinya, masyarakat harus teguh akan keyakinan dan ketakwaannya kepada Ida Sang Hyang Widhi, yang akan selalu siap mengayomi, menyelamatkan masyarakat dan siap menghadapi dan menghan-curkan kekuatan jahat yang ingin mengganggu manusia.

6. Pakaian barong landung, berbaju dengan lengan panjang, dan kain (wastra) serta selimut bawah (kampuh/saput) adalah simbol kematangan jiwa. Maknanya, sebelum berbuat masyarakat harus memikirkan dulu secara matang segala sesuatunya, agar tidak terjadi hal-hal yang tidak diinginkan yang dapat merusak citra dan martabat kemanusiaan.

7. Gerak barong landung yang terbatas, hanya mengayunkan sebelah tangan saja, hanya menggelengkan kepala dan menggoyangkan badan saja adalah simbol keterbatasan yang ada pada setiap diri manusia. Maknanya, setiap orang harus sadar sebagai makhluk ciptaan Tuhan yang memiliki keterbatasan masing-masing, dan saling membutuhkan satu sama lain. Sedangkan, gerakan keliling tempat suci dan upakara caru (kurban) sebanyak 3 kali yang sering dilakukan barong landung adalah simbol selalu awas dan selalu mengusir roh-roh jahat yang mengganggu lingkungan manusia. Hal ini menegaskan kembali fungsi barong landung 
sebagai makhluk mitologi penolak bala yang bersifat sakral, yang diyakini memiliki kekuatan gaib dalam melindungi pemujanya dari serangan roh-roh jahat.

8. Iringan musik barong landung adalah geguntangan, yang memiliki irama merdu dan lirih, selaras dengan kebutuhan tembang-tembang melodrama dalam lakon barong landung sehingga jelas tertengar oleh penikmatnya, melambangkan sentuhan kelembutan yang mampu dipersembahkan. Maknanya, kelembutan suara dapat memberikan sentuhan jiwa secara mendalam pada setiap orang.

9. Sesajen barong landung, gamelan maupun stage adalah simbol sujud bakti manusia terhadap kemahakuasaan Tuhan yang selalu membutuhkan sarana untuk mendekatkan diri kepada Beliau Yang Maha Kuasa.

10. Stage atau yang dalam bahasa bali dikenal dengan nama Kalangan yakni tempat pementasan barong landung yang biasanya terbuka dari segala arah, serta orientasi menghadap tempat suci atau bangunan pemujaan. Hal ini mangandung makna bahwa apapun yang seseorang kerjakan harus ditentukan arah atau tujuan pastinya, dan dalam mencapai tujuan tersebut harus selalu berorientasi disertai doa kehadapan Tuhan Yang Mahakuasa.

Kedua tokoh utama dalam cerita Barong Landung ini sudah menjadi mitologi yang begitu keramat di Bali, dan secara nyata dipuja sebagai Dewa oleh hampir sebagian besar masyarakat Bali. Kedua tokoh yang dilukiskan berwarna hitam dan berwarna putih merupakan perlambangan dari keadilan atau kewenangan serta kebijaksanaan untuk menentukan atau menegakkan kebajikan. Simbol-simbol ini terasa sangat serasi hal ini ada kaitannya dengan persamaan konsep religi orang Bali yang dikenal dengan istilah "Rwabineda" atau dalam istilah Cina dikenal dengan istilah "Im-Yang" yang juga memiliki kesamaan dalam tafsiran. Barong landung laki-laki merupakan simbol suci untuk memuja kebesaran raja Sri Jaya Pangus yang bertahta di Istana Panarajon, sekarang termasuk wilayah Desa Pinggan (Sukawana), Kecamatan Kintamani, Kabupaten Bangli. Barong landung wanita tua merupakan simbol 
dari permaisuri beliau, yang memiliki keturunan ras Mongoloid (Tionghoa). Secara kebetulan pula pada zaman pemerintahan raja suami istri ini terjadi suksesi penyatuan mazhab besar dalam agama Hindu di Bali ke dalam paham Siwa-Budha.

\section{b. Arti dan Asal Usul Barong}

Pada kamus Bahasa Bali karya Anandakusuma (1986) menyamakan barong itu dengan arti "berwujud binatang simbul kebaikan (barong ketket). Jadi dalam hal ini penekannya ditujukan pada arti yang mengkhusus yakni barong ket, padahal sebenarnya masih banyak jenis-jenis barong lain seperti : Barong Blas-blasanm, Barong Sae, Barong Kambing, Barong Singa, Barong Lembu, Barong Bangkal, Barong Asu, Barong Macan, Barong Gajah, Barong Jaran, Barong Menjangan yang kesemua berwujud binatang. Disamping itu ada juga barong yang mengambil wujud manusia, seperti Barong Landung, Barong Brutuk dan barong dawang-dawang. Dalam buku mengenal barong dan rangda karangan Nyoman Yasa Segara, S.Ag penerbit Paramita Surabaya tahun 2000 disebutkan bahwa secara etimologi, kata barong berasal dari bahasa sanskerta yaitu kata $\mathrm{b}(\mathrm{h})$ arwang yang di dalam bahasa Indonesia atau bahasa melayu sejajar dengan kata beruang yaitu nama seekor binatang yang hidup di benua Asia, Amerika dan Eropa, berbulu tebal dan hitam dengan ekor pendek. Di Indonesia binatang ini hidup di Sumatra dan Kalimantan, sedangkan di Bali beruang hampir tidak pernah dilihat dan dijumpai.

Kata beruang ini disamakan pula dengan wujud binatang yang lain, seperti: singa, macan, babi ataupun gajah. Kata $b(h)$ arwang sangat dekat maknanya (bersinonim) dengan bahasa Belanda beer yang artinya juga binatang beruang. Istilah binatang beruang mengidentifikasi wujud barong tidak lebih sebagai binatang mytology yang juga sering dijumpai pada cerita Tantri. Hal ini didasarkan pada kenyataan bahwa semua jenis pertunjukan yang menggunakan barong sama sekali tidak sesuai dengan apa yang sesungguhnya dimaksud dengan perkataan barong, malahan beberapa jenis 
pertunjukan yang sama sekali tidak ada unsur binatangnya disebut juga Barong.

Pendapat lain ada juga yang mengartikan kata Barong berasal dari asal kata -ru-ang. Dalam Bahasa Indonesia, huruf u dan a berasimilasi menjadi o, sehingga ru dan a (ng) menjadi ro (ng) yang berarti dua. Rong mengandung makna ruang, jadi dua rong yang dimaksud adalah dua ruang. Pengertian inipun dapat diterima karena pada umumnya barong mempunyai dua ruang sebagai tempat penarinya atau tempat mendutnya (bahasa Indonesia : menjunjung) kecuali barong jenis Blas-blasan dan Barong Landung. Selain itu ada juga pndapat yang mengatakan bahwa barong berasal dari plesetan kata bareng-bareng yang dalam bahasa Indonesianya berarti bersama-sama. Asumsi ini didasarkan pada kenyataan bahwa barong yeng berwujud manusia, raksasa maupun binatang dalam penampilannya tidak dapat dipisahkan dari partisipasi penduduknnya yang terdiri dari banyak orang, baik itu barong yang disakralkan maupun yang khusus di konsumsi untuk hiburan (profan).

Memperhatikan dan bertitik tolak dari pengertian-pengertian diatas, maka secara umum wujud Barong mengambil wujud binatang. Apabila kemudian ditemukan wujud dalam bentuk lain, itu hanya kreasi seniman, sangging. Dimana asal kebudayaan Barong sulit untuk diketahui karena yang pasti Barong tidak hanya ada di Bali tetapi juga dikenal di luar Bali dan bahkan di luar negeri seperti Cina dan jepang yang kemudian dibawa oleh Agama Budha. Kenyataan ini mendorong pikiran untuk menduga bahwa barong mungkin berasal dari unsur kebudayaan luar apalagi Jika dihubungkan dengan kenyataan lain dalam sejarah, bahwa Bali banyak menerima pengaruh kebudayaan asing terutama kebudayaan India dan Cina. Istilah Barong berasal dari India yaitu $b(h)$ arwang adalah bahasa sansekertha, walaupun tidak dapat dipastikan bahwa Barongnya sendiri juga dibawa dari India atau Cina. 


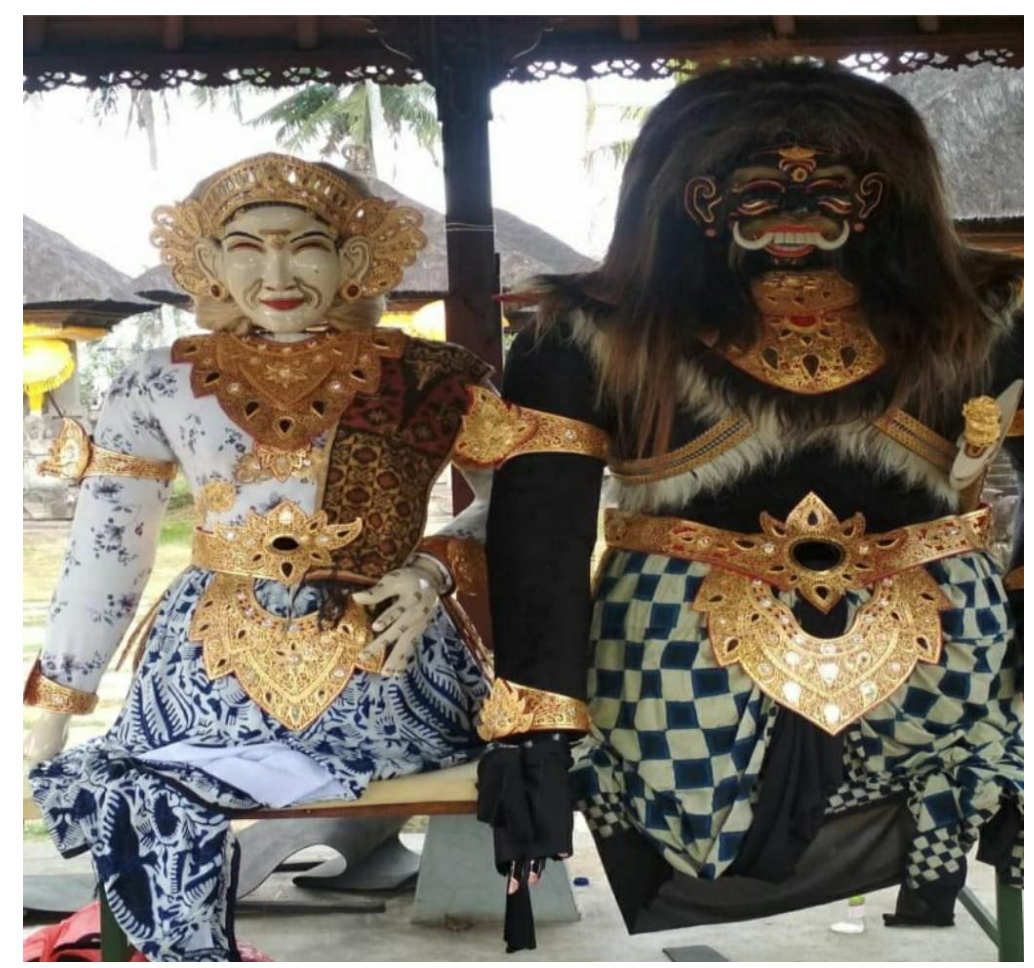

Gambar 1 Perwujudan Barong Landung (sumber : Dokumen Pribadi)

Terlepas dari kuat tidaknya pengaruh luar terhadap Barong yang berkembang di Bali, kenyataannya sebuah barang yang telah lahir dari kreasi seni dari masyarakat merefleksikan keyakinannya melalui wujud Barong.

Kelahiran seni barong ini mempunyai kecenderungan sesuai dengan teori yang nomor tiga yang telah dipaparkan dalam latara belakang yakni teori Magi dan Religi, sehingga tepat dengan judul yang dipilih oleh penulis. Diperkirakan keberadaan barong sudah mulai ada di Bali pada abad XVI dan itupun masih diragukan. Dan jika dikaitkan dengan data sejarah, pada abad XVI terutama pada masa pemerintahan Dalem Waturenggong di Bali adalah masa seni budaya Bali mencapai puncak keemasan. Sebagai contoh adanya relief Boma (wujud tapel barong ket) dan penyelidikan secara filologi terhadap data-data berupa kata-kata Banaspati, Calonarang dan yang lainnya cukup menguatkan tulisan ini. Sudah tentu kemungkinan-kemungkinan lainnya, seperti adanya kenyataan di Jepang dan Cina dimana Barong erat hubungannya dengan masuknya kebudayaan agama Budha, membuat kita beranalogi bahwa Barong mulai ada di Bali bersamaan dengan masuknya 
agama Budha ke Bali atau masuknya pengaruh Cina di Bali. Dan hanya sekedar mengambil analisir-analisir dari luar (Team Survey ASTI, 1977:109111).

Penelitian lain yang juga memiliki keterkaitan dengan kajian ini (Mudra, dkk, 2017) Hasil pemetaan terhadap seni pertunjukan di Bangli, diketahui ada lima Barong Landung). Namun dalam penelitian yang dilakukan, dipilih tiga objek, yaitu "Barong Landung Sakral" di Pura Penataran Sila dan Bangli; "Barong Landung Sakral” di Pura Siwa Pati Bukit Bangli; dan "Barong Landung Profan" (hiburan) di Yayasan Guru Kula. Sesungguhnya Barong Landung Yayasan Guru Kula juga dibuat sebagai bentuk duplikat dari Barong Landung sakral. Selain Barong Landung, ada lagi barong sakral lainnya yang dibuatkan duplikatnya tersimpan dalam museum, seperti Barong Asu, Barong Bangkung (Bangkal), Barong Ket, Barong Kedingkling, Barong Macan, dan Rangda. Dari semua barong duplikat yang ada, salah satu di antaranya adalah Barong Landung yang paling menarik dikomodifikasi, baik sebagai ikon seni rupa maupun seni pertunjukan.

Selain keberadaan Barong Landung di Bali, nampaknya Barong Landung juga merupakan salah satu kesenian orang lembak di Bengkulu yaitu barong landong yang lahir di Desa Tanjung Agung. Barong landong terinspirasi dari kebang-kebang yang ada di sawah sehingga diciptakan boneka berwujud sepasang manusia yang besar dan tinggi. Penciptaan barong landong diyakini mendapat pengaruh dari budaya Cina yang pada tahun 1800-an sudah banyak bermukim di Bengkulu sebagai pedagang. Kesenian Cina seperti barongsai memberikan inspirasi bagi orang lembak ketika itu untuk membuat media hiburan sehingga terciptalah boneka manusia besar yang dinamai barong landong. Nama barong (oleh masyarakat lembak disebut baghong) diambil dari bahasa Cina yang berarti sejenis boneka raksasa. Sedangkan nama landong (masyarakat lembak menyebut landung) berasal dari kosa kata lembak yang berarti tinggi atau panjang. Dengan demikian barong landong berarti boneka atau orang-orangan yang tinggi 
besar. Demikian juga asesoris pakaian pengantin yang dipakai oleh pengantin lembak dan barong landong banyak mendapat pengaruh budaya Cina (Arios, 2017:749-777).

Asal mula barong adalah dari Tari Singa Cina yang pada awalnya merupakan bentuk pengganti dari pertunjukan singa asli oleh para penghibur keliling profesional Selain di Bali dan Bengkulu keberadaan barong juga dapat dijumpai di beberapa tempat di Pulau Jawa, seperti di Magelang, Banyumas, Blora, Ponorogo, Banyuwangi, dan tempat lainnya. (Bandem, 2004:185).

Data dalam sejarah yang turut memberikan gambaran lain adalah ketika Raja Jayapangus memperistri seorang wanita Cina. Kemungkinan dalam perkawinan itu, wanita Cina tersebut membawa kebudayaannya ke Bali, sehingga ketika Raja Jayapangus dan putri Cina meninggal, rakyat Bali membuatkan simbol Barong yaitu Barong Landung. Barong Landung wanita memakai longdress dimana pakaian longdress ini adalah salah satu pengaruh kuat budaya Cina. Putri Cina ini dalam cerita sering disebut dengan Kang Ching Wie yang divisualisasikan dalam bentuk perempuan berkulit kuning dan bermata sipit yang memang merupakan tipikal orang Cina. Jika melihat fisik Barong Landung perempuan ini tampak jelas ada unsur Cina di dalamnya. Sedangkan Barong Landung yang laki-laki divisualisasikan dalam bentuk pria tinggi besar berkulit hitam gelap yang diyakini sebagai perwujudan Sri Jaya Pangus.

Sampai dengan saat ini, harus diakui perkembangan kesenian Barong Landung di Bali relatif statis. Tentunya tidak sepesat perkembangan tari kreasi, gong kebyar dan kesenian tradisional lainnya. Daerah sebenarnya relatif terbatas. Hanya terbatas di beberapa desa pemasyarakatn di kabupaten/kota yaitu Gianyar, Denpasar, Bandung dan Tabanan.

Griya (2000) dalam bukunya yang berjudul Transformasi Kebudayaan Bali Memasuki Abad XXI, merupakan kajian kebudayaan yang multi perspektif. Dipaparkan bahwa kebudayaan Bali sebagai salah satu kebudayaan nusantara telah mengalami transformasi kebudayaan akibat dari 
globalisasi. Gelombang transformasi kebudayaan Bali berlangsung sangat unik. Transformasi tersebut membuat berkembangnya beragam peluang dan ancaman terhadap budaya Bali, dari yang bernilai positif sampai negatif terkait dengan isu kebudayaan Bali kedepan.

Frekwensi pertunjukan Barong Landung yang divisualisasikan dengan wujud manusia tinggi besar inipun terbilang jarang. Pesona tarian ini umumnya hanya bisa dinikmati pada momen-momen khusus seperti hari besar keagamaan di Bali lebih dikenal dengan istilah Piodalan yang di laksanakan pada Pura tertentu. Kendati demikian, kesenian tradisional satu ini termasuk cukup tangguh mempertahankan eksistensinya di tengah dasyatnya gempuran arus modernisasi yang memberikan kontribusi yang cukup signifikan terhadap keterdesakan sejumlah kesenian tradisional di Bali.

Tetap ajegnya serta lestarinya Barong Landung di Bali lantaran jenis kesenian ini sangat kental dengan nuansa magis-religius. Dalam kesehariannya kesenian Barong Landung pada umumnya dipentaskan untuk kepentingan adat dan agama Hindu. Dalam konteks ini fungsi kesenian ini dapat digolongkan sebagai seni sakral atau seni wali. Karena berhubunggan dengan keyakinan umat, maka kesenian inipun tidak dipentaskan di sembarang tempat dan waktu. Artinya waktu pementasannya sangat mempertimbangkan hari baik dan lokasi pementasannya dipilih tempattempat yang dianggap sakral dan suci yang diawali prosesi mengahaturkan sesajen. 


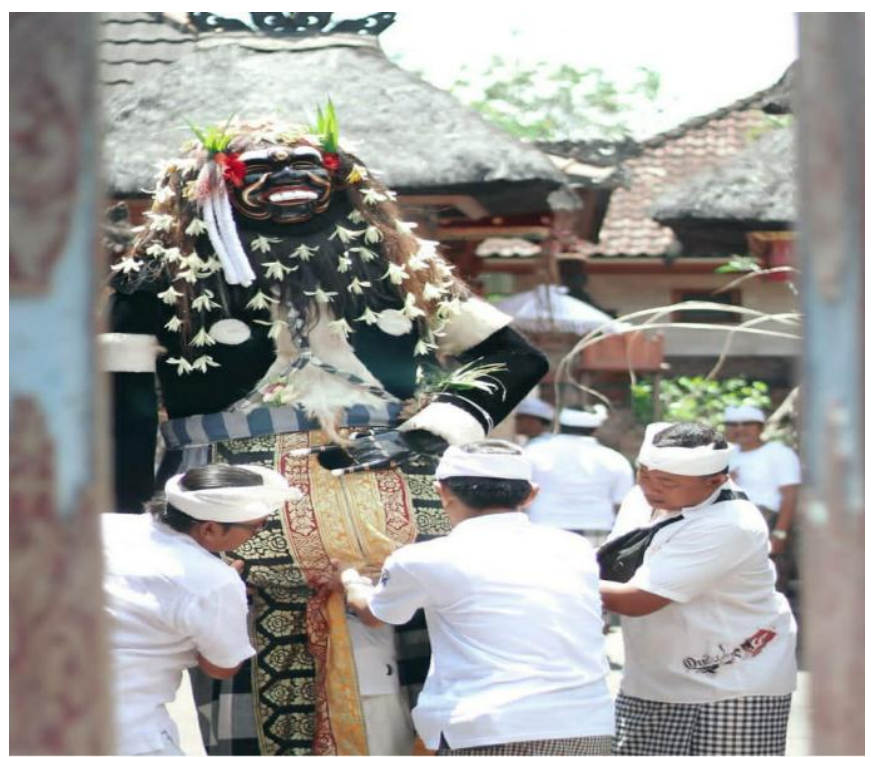

Gambar 2 Persiapan Sebelum Pementasan (sumber : Dokumen Pribadi)

Keberadaan kesenian Barong Landung di Bali umumnya memang sangat berkaitan dengan hal-hal yang bersifat magis-religius. Umat Hindu di Bali meyakini bahwa pementasan Barong Landung merupakan sarana untuk memohon keselamatan. Di sejumlah desa di Bali, keyakinan itu begitu mengkristal di hati masyarakat. Adanya keyakinan seperti ini secara otomatis akan menggerakkan masyarakat setempat khususnya dan masyarakat Bali umumnya untuk senantiasa melestarikan Barong Landung dari generasi ke generasi sehingga tidak sampai tergerus arus jaman. Masyakarat melestarikan kesenian ini dengan penuh kesadaran dan rasa tanggung jawab karena dipercaya punya andil yang sangat besar dalam menjaga ketentraman dan kesejahteraan masyarakat setempat dan sekitarnya secara lahir dan bhatin.

Beberapa bentuk simbol yang banyak dijumpai di Bali antara lain yang berbentuk binatang dapat berupa Barong simbul Dewa Siwa, Barong Bangkung sebagai simbul Dewa Wisnu, Naga Raksasa juga sebagai simbul Dewa siwa, Naga Anantaboga sebagai simbul Dewa brahma, Naga Basuki juga sebagai simbul Dewa Wisnu begitu juga Barong Landung (simbul Dewa Wisnu yang berbentuk manusia raksasa tinggi besar).

Barong Landung sebagai simbolisme, maka disebut juga sebagai benda suci menurut pandangan agama Hindu. Adapun pengertian benda- 
benda suci dalam keputusan seminar kesatuan tafsir terhadap aspek-aspek agama Hindu adalah benda-benda yang memang disucikan dengan melewati suatu upacara yang disebut "pesucian" tertentu yang fungsi dan penggunaannya semata-mata untuk tujuan suci dan ditempatkan pada tempattempat yang dipandang suci. Adapun jenis atau penggolonggan benda-benda suci yang dimaksud dalam pengertian tersebut diatas adalah : Pralingga, Arca, Pratima dan lain-lainnya yang sejenis (Swadiana, 2008: 16).

\section{Pura Dalem Balingkang dan Keterkaitannya Dengan Barong Landung}

Pura Dalem Balingkang berlokasi di Desa Pinggan, Kecamatan Kintamani Kabupaten Bangli berjarak sekitar 80 km dari Denpasar mengikuti jalur Denpasar - Singaraja melewati Kintamani. Kemudian di Pura Puncak Penulisan menuju ke arah Timur Laut lokasi ini sangat unik dikelilingi oleh sungai melilit yang dahulu dianggap sebagai benteng utama yang mengelilingi serta sebagai pelindung kerajaan Balingkang.

Pada masa itu, masyarakat Bali terbagi menjadi dua kelompok utama, Bali Mula atau Bali Aga dan Bali majapahit. Prof. Dr. I Gusti Ngurah Bagus (alm) dalam tulisannya "Kebudayaan Bali (1979) menyebutkan masyarakat Bali Mula mendiami daerah pengunungan di Bali, sedangkan Bali Majapahit mendiami daerah daratan.

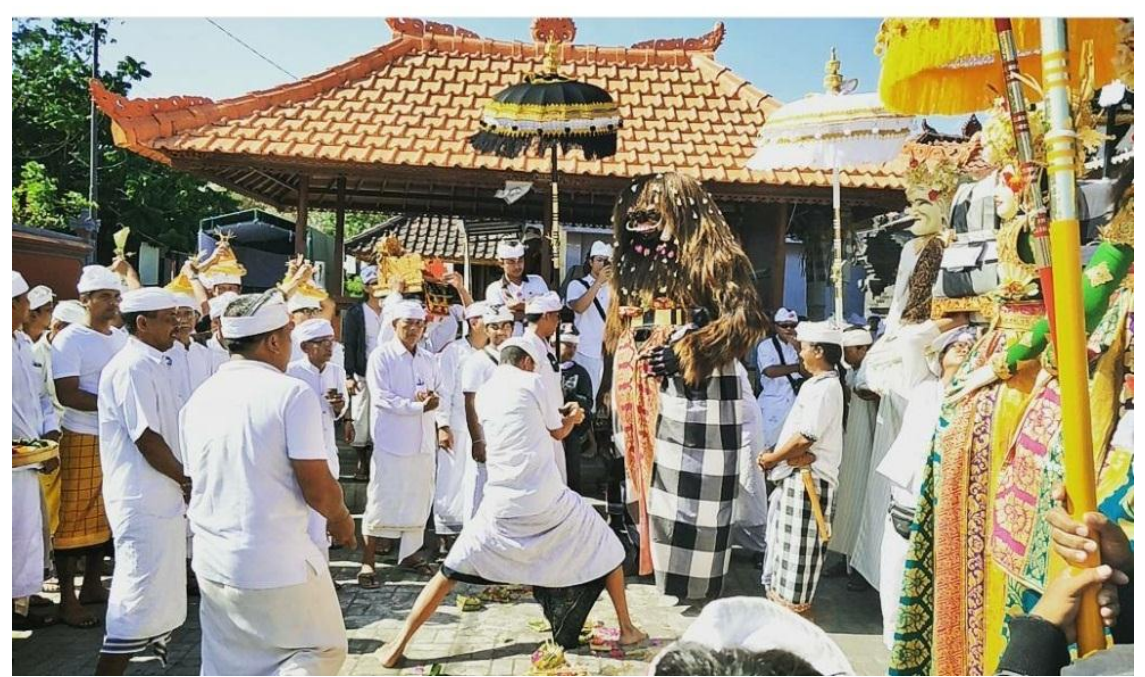

Gambar 3 Prosesi Pementasan Barong Landung (sumber : Dokumen Pribadi) 


\section{c. Raja Dengan Dua Permaisuri}

Dalam konteks Pura Dalem Balingkang, Nama Balingkang berasal dari kata Bali + ingkang. Secara tuturan dan bukti tertulis, hal ini dikaitkan dengan pernikahan Raja jaya Pangus Harkajalancana yang memerintah pada tahun Saka 1103 - 1191 atau 1181 -1269 Masehi. Raja Jaya Pangus mempunyai dua permaisuri yakni Paduka Bhatari Sri Parameswari Indujaketana dan Paduka Sri Mahadewi Cacangkaja Cihna (cihna -cina). Dalam cerita rakyat yang berkembang disebutkan istri Cina nya bernama Kang Cing Wie putri tuan Subandar saudagar dari Cina. Maka digabungkan Bali-Ing Kang menjadi Balingkang.

\section{Sri Jaya Pangus-Kang Cing Wie}

Bagus (2005: 658) mengatakan mitos mempunyai arti asli, yaitu kisah, hikayat dari zaman purbakala (mitos-mitos tentang para pahlawan dan para dewa) yang sangat berpengaruh atas kehidupan dan kebudayaan bangsa-bangsa. Mitos, dalam bahasa Inggris: myth; dari Yunani mythos (mitos, mite, fibula, hikayat, legenda, percakapan, ucapan, pembicaraan), myhteomai $=$ (menceritakan, menghubungkan). Mitos dianggap sebagai pandangan hidup atau Weltanschauung yang intuitif, imajiner, yang lazimnya dipersonifikasi. Mitos dapat juga dikatakan sebagai cerita yang asal-usulnya sudah dilupakan, mengungkapkan peristiwaperistiwa yang menyangkut orang-orang penting dalam masyarakat dan yang mempunyai kesadaran sosial. Mitos diyakini dengan cara- cara ritual dan cara-cara lain, ikatan-ikatan sosial, adat-istiadat, dan ikatan. Mitos juga adalah sebuah kebenaran yang belum didukung dengan fakta-fakta.

Kisah Barong Landung misalnya yang diambil dari hikayat Sri Jaya Pangus, yang merupakan Raja Bali dari dinasti Warmadewa. Kerajaannya berpusat di Penarajon sebelah utara Kintamani. Sri Jaya Pangus melanggar adat yang sangat ditabukan saat itu, yakni mengawini putri Cina yang bernama Kang Cing Wie. Raja Jaya Pangus tetap ngotot kawin meski tidak direstui pendeta kerajaan Mpu Siwa Gandu. Akibatkan sang pendeta marahmarah, lalu menciptakan hujan terus-menerus yang menyebabkan seluruh kerajaan tenggelam (Atmodjo, 1970: 23). 
Jaya pangus yang tetap melawan, akirnya kerajaan dipindahkan ketempat lain. Nama itu disebut Balingkang yang berasal dari Bali ditambah Kang nama depan istrinya dan rakyatnya menyebut rajanya dengan Dalem Balingkang. Sayangnya pasangan ini tidak berhasil memperoleh keturunan. Oleh karena itu Dalem Balingkang kemudian memohon kepada Dewa yang bersemayam di Gunung Batur agar dikaruniai anak-anak. Tetapi bukan anak yang diperoleh langsung dari istrinya Kang Cing Wie, namun malah beliau justru terpicut dengan kemolekan seorang putri yang dijuliki Dewi Danuh. Dalem Balingkang pun terpikat, lalu kawin diam-diam tanpa sepengetahuan putri Kang. Sementara itu Kang Cing Wie tentu saja gelisah ditinggal suaminya berlama-lama. Ia pun kemudian menyusul ke Gunung Batur. Ditengah hutan belantara yang lebat, putri Kang terkejut menemukan suaminya telah menjadi milik Dewi Danuh. Ketiganya lalu terlibat pertengkaran sengit. Dengan kekuatan dan kesaktiannya Dewi Danuh mampu mengalahkan Dalem Balingkang dan Kang Cing Wie hingga hilang ditelan Bumi. Meskipun hilang tanpa bekas, rakyat yang mencintai Dalem Balingkang dan Kang Cing Wei, lalu dibuatkan patung sebagai simbul keduanya. Kedua patung inilah yang kemudian berkembang menjadi Barong Landung. Karena itu Jika diperhatikan wajah Jero Luh beserta aksesoris busananya memang merupakan budaya Cina. Kemudian keduanya dipuja oleh rakyatnya di Pura Dalem Balingkang (Sulistyawati, 2011: 83 dan Swadiana, 2008: 13).

\section{Istana Raja Sri Kesari Warmadewa}

Berjarak sekitar $40 \mathrm{~km}$ dari kota Bangli tepatnya di Desa Pinggan Kecamatan Kintamani. Dalem Balingkang bertempat di daerah terpencil disebelah utara Danau Batur dan disebelah timur Bukit penulisan. Tempat yang sangat indah ini begitu mudah dicapai dengan kendaraan sampai di areal parkir pura. Dari tempat parkir, pengunjung bisa berjalan 500 meter untuk mencapai pura. 
Kata Balingkang berarti "Raja Bali" dan pura ini pernah dijadikan istana oleh Raja Bali. Berdasarkan cerita rakyat, pada abad 11 ada seorang raja bernama Sri Kesari Warmadewa beliau bersama permaisuri (permaisuri) dikisahkan dalam tari Barong Landung yang sering dipentaskan di Bali hingga sekarang.

Bangunan di Pura Dalem Balingkang telah dipengaruhi oleh design dan arsitektur Cina, diantaranya bangunan Gedong Mas dan Palinggih Ida Ratu Ayu. beliau juga membawa uang logam (kepeng) bersisi dua yang pada sisinya memiliki ciri khas Bali sebagai simbul Ketuhanan. Sampai sekarang uang ini masih dimanfaatkan sebagai sarana ritual di Bali. Sri Kesari Warmadewa memiliki seorang putra bernama Sri Aji Jaya Sakti. Kerajaannya meliputi Desa Rejasa Tangga, Batan Tingkih, Seluni Pulu, Bun Bulan, Nyungle, Tanggun Titi, Tegallinggah, dan Puri Balingkang.

Sri Jaya Sakti mengawini Sri Asnyaswari yang asalnya tidak diketahui. Beliau memiliki putra diantaranya Sri Jaya Pangus dan Masulamasuli. Setelah putra-putranya dewasa, Sri Aji Jaya Sakti berkelana dan tergila-gila pada seorang anak yang bernama Sri Mayadanawa.

Sri Jaya Pangus pergi ke gunung Indrakila dan mendirikan kerajaannya sendiri. Beliau mengajak Asnyaswari menuju Besakih bersama putranya yang lain dan dipungut oleh Ki Wenara Petak. Sementara itu, diistana Balingkang terjadi perseteruan antara Sri Aji Jaya Sakti dengan mayadanawa. Karena kekalahannya itu, Sri Aji Jaya Sakti mengungsi ke Gunung kembang Rijasa dimana berjumpa dengan seorang pertapa yang berhasil mengobati matanya yang buta. Beliau mengikuti pertapa itu ke arah untuk menemani Sang Hyang Song.

Setelah tiba di suatu tempat Sri Aji Jaya Sakti bermeditasi sampai akhirnya memperoleh wangsit dari Ibunya. Beliau diwajibkan mendirikan pura sebagai tempat memuja Sang Hyang Song. Tahta kerajaan telah diiserahkan kepada putranya masula-masuli diperintahkan untuk menyingkirkan mayadenawa. Akhirnya masula-masuli berhasil merebut kembali tahta ayahnya. Pusat kerajaannyapun dibatasi dengan sungai yang 
disucikan dan dipagari pepohonan dan bunga-bungaan. Pura ini kemudian dikenal sebagai Pura Dalem Balingkang.

Pura Dalem Balingkang disembah oleh seluruh umat Hindu dari seluruh pelosok di Bali. Pemandangan alam sekitarnya sangat menakjubkan menambah keindahan panoramanya. Bila dibandingkan era tahun lima puluhan dengan sekarang, Pura Dalem Balingkang sudah mengalami banyak perubahan. Perubahan ini diantaranya, dulu warga yang akan sembahyang ke Dalem Balingkang kebanyakan datang dari arah bawah menyusuri perbukitan sekarang Para umat yang hendak bersembahyang ke Pura Dalem Balingkang sudah dapat memakai mobil sampai tepat di depan Pura. Jembatan yang menghubungkan areal pura dan jaba sisi dulu dengan bambu sekarang sudah memakai beton. Secara fisik banyak yang sudah mengalami perubahan, ada tambahan apit lawang, candi bentar, palinggih ayu subandar atau pusering tasik.

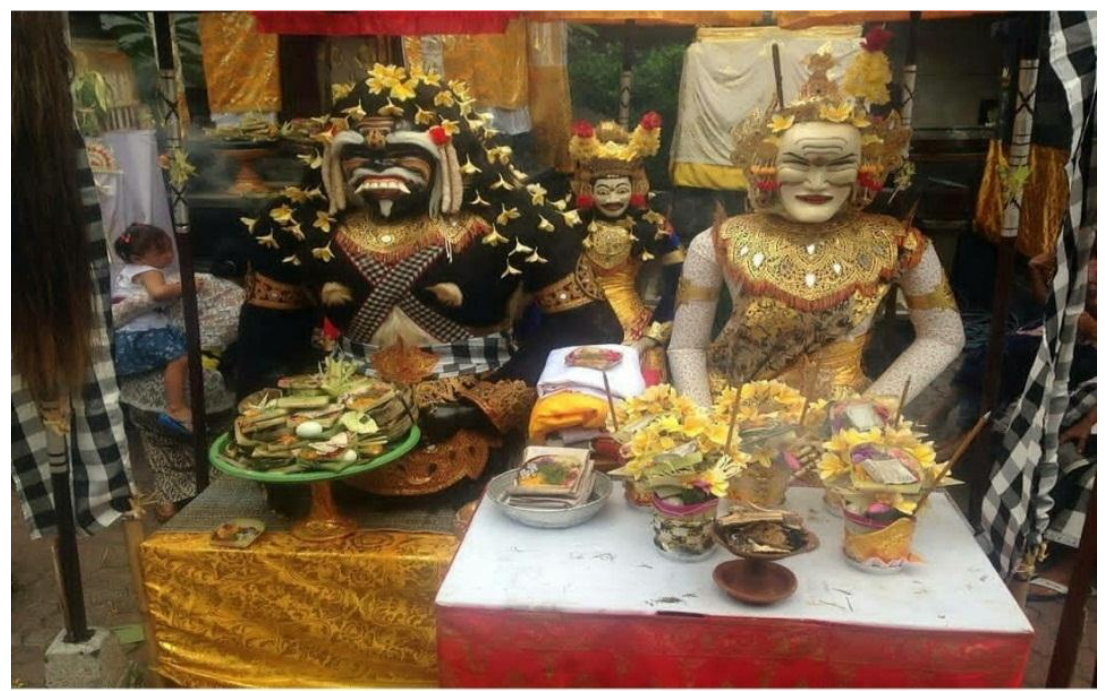

Gambar 4 : Prosesi Mengahturkan Sesajen sebelum Pementasan dimulai. (sumber: Dokumen Pribadi)

\section{PENUTUP}

Sejarah Muncunya Barong Landung yakni merupakan perkawinan antarbudaya Cina dan Bali. Adalah ketika Raja Jayapangus memperistri seorang wanita Cina yang kemungkinan dalam perkawinan itu, wanita Cina tersebut membawa kebudayaannya ke Bali, sehingga ketika Raja Jayapangus 
dan putri Cina meninggal, rakyat Bali membuatkan simbol Barong yaitu Barong Landung. Jika disimpulkan adalah perwujudan dari sang Maha Pencipta, yang oleh undagi di masa lalu tentu diwujudkan sesuai dengan keadaan zamannya ketika itu.

Barong Landung sebagai simbolisme, maka disebut juga sebagai benda suci menurut pandangan agama Hindu. Adapun pengertian bendabenda suci dalam keputusan seminar kesatuan tafsir terhadap aspek-aspek agama Hindu adalah benda-benda yang memang disucikan dengan melewati suatu upacara yang disebut "pesucian" tertentu yang fungsi dan penggunaannya semata-mata untuk tujuan suci dan ditempatkan pada tempattempat yang dipandang suci.

Pura Dalem Balingkang dan Keterkaitannya Dengan Barong Landung yakni kisahnya diambil dari hikayat Sri Jaya Pangus, Raja Bali dari dinasti Warmadewa. Kerajaannya berpusat di Penarajon sebelah utara Kintamani. Sri Jaya Pangus melanggar adat yang sangat ditabukan saat itu, yakni mengawini putri Cina yang bernama Kang Cing Wie. Raja Jaya Pangus tetap ngotot kawin meski tak direstui pendeta kerajaan Mpu Siwa Gandu. Akibatkan sang pendeta marah-marah, lalu menciptakan hujan terus-menerus sehingga seluruh kerajaan tenggelam 


\section{DAFTAR PUSTAKA}

Arios, Rois Leonard. 2017. "Barong Landong: Fungsi dan Pelestariannya Sebagai Identitas Budaya Orang Lembak Di Kota Bengkulu. Jurnal Penelitian Sejarah dan Budaya, Vol. 3 No. 2. Hal 749-771

Bandem, I Made. 2004. Kaja dan Kelod: Tarian Bali dalam Transisi.. Jogyakarta: Badan Penerbit ISI Jogyakarta

Bandem, I Made. 2011. Gamelan Bali Di Atas Panggung Sejarah. Denpasar: Badan Penerbit STIKOM Bali.

Budhiartini Pan Putu. 2000. Rangda Dan Barong Unsur Dualistik Mengungkap Asal Usul Umat Manusia, Lampung Tengah.

Dibia, I Wayan. 2000. Tari wali. Denpasar : Dinas Kebudayaan Propinsi Bali.

Gadung, Ni Ketut. (2008). "Kesenian Barong Landung di Banjar Kaja Pedungan: Sebuah Kajian Budaya." Tesis Program Magister Kajian Budaya, Program Pascasarjana Universitas Udayana, Denpasar.

Griya, I Wayan. 2000. Transformasi Kebudayaan Bali Memasuki Abad XXI. Denpasar : Dinas Kebudayaan Propinsi Bali.

Hans Daeng, Manusia, Kebudayaan dan Lingkungan, Yogyakarta: Pustaka Pelajar, 2000.

Koentjaraningrat, Kebudayaan, Mentalitas dan Pembangunan. Jakarta: Gramedia

Mudra, I Wayan, dkk. 2017. "Data Seni Rupa \& Desain di Kecamatan Susut dan Bangli serta Tembuku Kabupaten Bangli Provinsi Bali”. Kerja sama Kementerian Riset, Teknologi dan Pendidikan Tinggi Lembaga Penelitian, Pengabdian kepada Masyarakat dan Pengebangan Pendidikan Institut Seni Indonesia Denpasar dengan Dinas Pariwisata dan Kebudayaan Kabupaten Bangli Nomor: 254/IT5.3/ PG/2017 dan 431/226/ Dispabud/ 2017.

Panitia Pelaksana Seminar Kesatuan Tafsir, 2007. "Keputusan Seminar Kesatuan Tafsir terhadap Aspek-aspek Agama Hindu”, Surabaya: Paramita.

Sedyawati, Edi. 2014. Kebudayaan di Nusantara. Dari Keris, Tor-tor sampai Industri Budaya. Depok: Komunitas Bambu 
Subagiasta, I Ketut, 2007. Etika Pendidikan Agama Hindu. Surabaya:, Paramita.

Surasmi, I Gusti Ayu. 2007. Jejak Tantrayana di Bali, Denpasar, CV. Bali Media Adhikarsa.

Swadiana, Oka. 2008. Barong Landung Bernuansa : Magis-Religius. Surabaya: Paramitha.

Swadiana,Oka. 2008. "Kesurupan Membahas Tradisi Kerauhan di Bali”, Denpasar: Raditya.

Swadiana,Oka. 2008. Ngurek : Pengorbanan Diri Pemuja Shakti. Denpasar: Raditya.

Triguna, Ida Bagus Gede Yudha. 2000. Teori Tentang Simbol. Denpasar : Yayasan Widya Dharma Universitas Hindu Indonesia.

Warna, I Wayan. 1993. Kamus Bali-Indonesia. Denpasar: Dinas Pengajaran Daerah Tingkat I Bali.

Wiana, I.K, 2003. Makna Upacara Yadjna Dalam Agama Hindu. Surabaya: Paramita

Wijaya, Ni Luh Nesa Swasthi. 2001. "Barong dan Rangda Sungsungan sebagai Pengukuhan Integritas Sosial". Mudra: Jurnal Seni Budaya. No. 10 Th. IX Januari 2001. Denpasar: UPT Penerbitan STSI Denpasar.

Yoga Segara, Nyoman, Mengenal Barong dan Rangda. Surabaya: Paramita.

Yudabakti, I Made. 2007. Filsafat Seni Sakral dalam Kebudayaan Bali. Surabaya: Penerbit Paramita. 